\title{
NITROGEN OXIDES ON THE SOUTH AFRICAN HIGHVELD
}

\author{
Kristy Ross ${ }^{1}$, Stephen Broccardo ${ }^{2}$, Klaus-Peter Heue ${ }^{3}$, Kirsten Ferguson ${ }^{2}$ and Stuart Piketh ${ }^{2}$ \\ 1 Eskom Research and Innovation Department, Eskom, Johannesburg, \\ kristy.ross@eskom.co.za \\ 2 Climatology Research Group, University of the Witwatersrand, Johannesburg \\ 3 University of Heidelberg, Germany
}

\begin{abstract}
Satellite retrievals have highlighted the South African Highveld as a region with one of the highest nitrogen oxide $\left(\mathrm{NO}_{\mathrm{x}}\right)$ emission densities in the world. There are numerous sources of $\mathrm{NO}_{\mathrm{x}}$ on the Highveld, including coal-fired power stations, petrochemical and other industries, motor vehicles and lightning, but surface measurements of $\mathrm{NO}_{\mathrm{x}}$ have not indicated that there is any cause for concern. A number of research initiatives are being undertaken in an attempt to resolve the discrepancy between surface measurements and satellite retrievals of $\mathrm{NO}_{\mathrm{x}}$. An assessment of ground-level concentrations in various environments, including industrial and urban regions, has shown that $\mathrm{NO}_{\mathrm{x}}$ levels recorded in the low-income urban area are significantly higher than those recorded downwind of industries or power stations. $\mathrm{NO}_{2}$ column densities have been remotely sensed over the Highveld using an airborne imaging Differential Optical Absorption Spectrometer (iDOAS), in order to validate the satellite retrievals and investigate individual sources of $\mathrm{NO}_{\mathrm{x}}$. Results from the first campaign show high $\mathrm{NO}_{2}$ integrated column densities in the immediate vicinity of sources. Well defined plumes can be observed downwind of prominent sources.
\end{abstract}

\section{Keywords}

Nitrogen dioxide, Highveld, DOAS, remote sensing, power stations, satellite

\section{Introduction}

The South African Highveld has been identified by satellite retrievals as an area of elevated nitrogen oxide $\left(\mathrm{NO}_{\mathrm{x}}\right)$ concentration. Nitrogen oxides play a significant role in the chemistry of the atmosphere (Seinfeld and Pandis, 1998). $\mathrm{NO}_{\mathrm{x}}$ is linked to the oxidizing effectiveness of the troposphere, directly via its role in the production of 03 and indirectly via its impact on the hydroxy! radical $(\mathrm{OH}) . \mathrm{NO}_{\mathrm{x}}$ is of great concern because it is toxic in the form of nitrogen dioxide (NO2), and tropospheric ozone $\left(\mathrm{O}_{3}\right)$ which may be formed from $\mathrm{NO}_{\mathrm{x}}$ is a greenhouse gas and is harmful to human health and vegetation. Concern has also been expressed about the high rates of nitrogen deposition and the consequences thereof (Lee etal, 1997)

Several research initiatives are currently underway to validate the $\mathrm{NO}_{\mathrm{x}}$ 'hotspot' identified by satellite images, and to understand reactive nitrogen on the South African Highveld. $\mathrm{NO}_{\mathrm{x}}$ measurements from four ground-based sites across the Highveld have been analysed in an attempt to ascertain baseline $\mathrm{NO}_{\mathrm{x}}$ levels in different environments, and an imaging Differential Optical Absorption Spectrometer (iDOAS) has been flown on a research aircraft over the Highveld in order to validate the satellite retrievals and obtain high resolution imagery of $\mathrm{NO}_{2}$ column densities over the region. Results of these studies will be discussed.

\section{Formation and sources of nitrogen oxides}

$\mathrm{NO}_{\mathrm{x}}$ (which consists of nitric oxide $(\mathrm{NO})$ and $\mathrm{NO}_{2}$ ) is formed when atmospheric nitrogen is oxidised during high temperature combustion $(>2000 \mathrm{~K})$ and electrical discharges, and by biogenic activity of micro-organisms within soil (Beirle, 2004). $\mathrm{NO}_{\mathrm{x}}$ is primarily emitted as $\mathrm{NO}$ and rapidly oxidises when it comes into contact with 03 molecules to form $\mathrm{NO}_{2}$ (equation $\mathrm{R} 2$ ). $\mathrm{NO}$ is also oxidized through the reaction with oxygen $\left(2 \mathrm{NO}+\mathrm{O}_{2}-->\right.$ $2 \mathrm{NO}_{2}$ ), but the reaction with $\mathrm{O}_{3}$ dominates at ambient atmospheric conditions (Seinfeld and Pandis, 1998; Beirle, 2004). NO is emitted directly into the troposphere via nitrogen fixation (equation $\mathrm{R} 1)$.

$$
\begin{aligned}
& \mathrm{N} 2+\mathrm{O}_{2} \rightarrow 2 \mathrm{NO} \\
& \mathrm{NO}+\mathrm{O}_{3}-->\mathrm{NO}_{2}+\mathrm{O}_{2}
\end{aligned}
$$

Natural tropospheric $\mathrm{NO}_{\mathrm{x}}$ concentrations are around $10-20 \mathrm{ppt}$, but concentrations exceeding $200 \mathrm{ppb}$ can be found in urban areas (Leue et al., 2001). $\mathrm{NO}_{\mathrm{x}}$ is emitted from sources which provide the high temperature combustion (or microbial action for soil emissions) which is required to split the $\mathrm{N}_{2}$ molecule which combines with $\mathrm{O}_{2}$ to create $\mathrm{NO}_{\mathrm{x}}$. Sources of $\mathrm{NO}_{\mathrm{x}}$ are both natural and anthropogenic. 


\section{Fossilfuel burning}

Combustion of fossil fuels is the greatest sources of tropospheric $\mathrm{NO}_{\mathrm{x}}$ emissions globally, and it is estimated that $\mathrm{NO}_{\mathrm{x}}$ emissions from fossil fuel combustion have more than doubled over the last century (Lee et al., 1997). The high temperature combustion of fossil fuels facilitates the formation of NO. Coal- and gas-fired power stations constitute about a third of global anthropogenic $\mathrm{NO}_{\mathrm{x}}$ emissions (Sillman, 2000). Major industrial and power plant sources of $\mathrm{NO}_{\mathrm{x}}$ on the Highveld are shown in Figure

\section{Emissions from motor vehicles}

Due to the high temperatures in internal combustion engines, atmospheric $\mathrm{N}_{2}$ combines with $\mathrm{O}_{2}$ resulting in $\mathrm{NO}_{\mathrm{x}}$ formation. It is estimated that $70 \%$ of tropospheric $\mathrm{NO}_{\mathrm{x}}$ in urban areas comes from motor vehicles. There are usually marked maxima in $\mathrm{NO}_{\mathrm{x}}$ concentrations during peak hour traffic times in both the morning and evening (Lal and Patil, 2001).

\section{Aircraft emissions}

$\mathrm{NO}_{\mathrm{x}}$ emissions from aircraft constitute a very small amount in comparison with other sources (Lee et al., 1997; Beirle, 2004). These emissions are important in the upper troposphere $(8-12 \mathrm{~km})$ where intercontinental flights occur (Beirle, 2004).

\section{Lightning}

Lightning is the largest natural source of tropospheric $\mathrm{NO}_{\mathrm{x}}$. According to Lee et al. (1997) lightning contributes $\sim 12 \%$ of total $\mathrm{NO}_{\mathrm{x}}$ emissions globally, although this estimate is extremely uncertain. In South Africa, it has been estimated that lightning contributes $\sim 25 \%$ of tropospheric $\mathrm{NO}_{x}$ over the Highveld (Wenig et al., 2003). High lightning $\mathrm{NO}_{\mathrm{x}}$ concentrations are found over parts of the Highveld during summer, due to the nigh intensity of electrical storms (Annegarn et al, 2003; Figure 2). The area of highest lightning frequency coincides with the eastern Highveld, where most power stations are concentrated.

\section{Biomass burning}

In southern Africa, biomass burning mainly contributes to ambient $\mathrm{NO}_{\mathrm{x}}$ concentrations during late winter and spring.

\section{Biogenic soil emissions}

$\mathrm{NO}_{\mathrm{x}}$ is produced in soils by the biogenic activity of micro-organisms through denitrification (a conversion to free nitrogen) and nitrification (conversion of $\mathrm{NH}_{4}^{+}$into $\mathrm{NO}_{3}$ - then into $\mathrm{NO}_{2}$ ) $(\mathrm{Lee}$ et al., 1997; Seinfeld and Pandis, 1998). Soils emit greater concentrations of NO than NO2. The level of $\mathrm{NO}_{\mathrm{x}}$ emissions is determined by the soil moisture content. Soils with low moisture content exhibit nitrification, resulting in higher emissions of NO, whilst wetter soils promote denitrification and NO emissions are much lower. Over northern South Africa, drier savanna areas are common, thus the production of NO is favoured (Parsons and Scholes, 1996). However, biogenic soil emissions constitute a small percentage of total $\mathrm{NO}_{\mathrm{x}}$ emissions.

\section{Injection from the stratosphere}

$\mathrm{NO}_{\mathrm{x}}$ that is naturally produced through the destruction of $\mathrm{N} 2 \mathrm{O}$ in the stratosphere may be transported into the troposphere in tropopause folding events (Seinfeld and Pandis, 1998). During these events, tongues of stratospheric air push into the troposphere transporting $\mathrm{NO}_{\mathrm{x}}$ with them (Seinfeld and Pandis, 1998). These events occur predominantly in spring, but stratospheric injections constitute a very small percentage of $\mathrm{NO}_{\mathrm{x}}$ production (Lee et al, 1997).

\section{Surface measurements of $\mathrm{NO}_{\mathrm{x}}$}

An assessment of surface $\mathrm{NO}_{\mathrm{x}}$ levels has been conducted using continuous $\mathrm{NO}_{\mathrm{x}}$ measurements collected at four of Eskom's active ambient air quality monitoring stations. These stations are in an industrial area (Elandsfontein); directly $(2 \mathrm{~km})$ downwind of a power station (Kendal); in a township (Dhlamini, Soweto); and some distance downwind of the industrialised region (Verkykkop) (Figure 3). Source Apportionment by Diurnal Signature (SADS) analysis (a tool developed by Clive Turner at Eskom to perform source apportionment based on the mean diurnal hourly average pollutant concentrations) has been performed to identify major source types affecting the different regions.

At sites mainly impacted by industrial and power station emissions (Elandsfontein, Kendal and Verkykkop), $\mathrm{NO}_{\mathrm{x}}$ concentrations are highest during the day, reflecting the influence of tall stack sources (Figure 4). Surface inversions prevent NO from reaching the ground at night, but pollutants are brought to the surface during the day under convective boundary layer conditions. SADS analysis confirms that tall stacks are the dominant source of NO in the 
industrial source region, with contributions of $65 \%$ and $68 \%$ at Elandsfontein and Kendal, respectively (Figure 5).

Nevertheless, average $\mathrm{NO}_{x}$ concentrations are low in and downwind of the industrial region. Average hourly concentrations of $\mathrm{NO}$ and $\mathrm{NO}_{2}$ are less than $7 \mathrm{ppb}$ at Elandsfontein and less than $10 \mathrm{ppb}$ at Kendal (compare to the average annual proposed NO2 ambient air quality standard of $21 \mathrm{ppb}$ ). Very low $\mathrm{NO}_{\mathrm{x}}$ concentrations (less than $5 \mathrm{ppb}$ ) are recorded at Verkykkop due to its distance from $\mathrm{NO}_{\mathrm{x}}$ sources. NO2 concentrations at Verkykkop are twice the magnitude of $\mathrm{NO}$ concentrations on average, indicating that the airmass is well aged. The source apportionment by diurnal signature indicates that tall stacks, vehicles and background contribute equally to total NO downwind of the Highveld.

$\mathrm{NO}_{\mathrm{x}}$ concentrations are significantly higher and the diurnal profile differs at the low-income urban site, where average hourly NO concentrations peak at over $50 \mathrm{ppb}$ in the morning and evening (Figure 4 ). The morning and evening $\mathrm{NO}_{x}$ peaks reflect the influence of local vehicle emissions and domestic coal combustion at the site. Emissions are highest in the early morning and evening when traffic is heaviest and coal is burnt for cooking and heating, and the accumulation of pollutants is exacerbated by surface temperature inversions which trap the pollutants. The contribution of the low-level sources is confirmed by the SADS analysis, which attributes $96 \%$ of the NO to vehicles, domestic burning and background (Figure 5).

The characteristic diurnal cycle in ozone concentrations, with higher ozone concentrations during the day as a result of in-situ production, is evident at all sites (Figure 4). At Verkykkop the ozone diurnal cycle is dampened in comparison to the other regions. Ozone concentrations are generally lower at Kendal and Dhlamini, and increase with distance from the major $\mathrm{NO}_{\mathrm{x}}$ sources.

\section{Remote sensing of $\mathrm{NO2}$}

Satellite retrievals indicate that $\mathrm{NO}^{*}$ emission densities on the Highveld are similar to those in the highly industrialized regions of east Asia, Europe and the north-eastern United States (Figure 6). Satellites also provide evidence of the long-range transport of $\mathrm{NO}_{\mathrm{x}}$ from the Highveld over the Indian Ocean (Wenig et al, 2003). However, the spatial resolution of the satellite instruments is fairly coarse (tens to hundred of kilometers), and it is not possible to resolve single point sources, or to ascertain with any degree of accuracy the extent of the $\mathrm{NO}_{\mathrm{x}}$ 'hotspot' on the Highveld. There is also a discrepancy between satellite and ground-based observations, as surface measurements of NO; are generally low, and do not suggest that $\mathrm{NO}_{2}$ column densities on the Highveld would be so high.

In order to validate the satellite retrievals on a regional scale and investigate individual sources on a local scale, a project is being conducted by Eskom, the University of the Witwatersrand, the South African Weather Service and the University of Heidelberg, Germany. An imaging Differential Optical Absorption Spectrometer (iDOAS) has been mounted on the South African Weather Service's research aircraft. The iDOAS measures reflected light in the visible and ultraviolet wavelengths, along a line perpendicular to the aircraft track. Combined with the aircraft's forward motion, this produces a two-dimensional image (Figure 7). $\mathrm{NO}_{2}$ total and tropospheric column densities are retrieved using differential optical absorption spectroscopy. Flights are focused on the Highveld, and coincide with satellite overpasses when possible. Test flights were conducted in October 2006, and a winter campaign was conducted in August 2007. A summer campaign is planned for February 2008.

A flight over the Mpumalanga Highveld was conducted on 5 October 2006. The $\mathrm{NO}_{2}$ tropospheric column density, as derived from Ozone Measuring Instrument (OMI) data, is shown in Figure $8 . \mathrm{NO}_{2}$ column densities were highest over the Mpumalanga Highveld, and over the JohannesburgPretoria and Vereeniging-Vanderbijl regions (seen as isolated sources to the west of the main hotspot on the satellite image).

The airborne DOAS measurements indicate that there is considerable variation in $\mathrm{NO}_{2}$ slant column density (SCD) over the Mpumalanga Highveld, however. $\mathrm{NO}_{2}$ column densities are highest immediately downwind of major sources, and plumes are discernible tens of kilometres downwind of the sources. On this occasion the plumes from Matla, Kriel and Kendal merged to form one large plume which was advected to the east-south-east. It is likely that the joining of the plumes from Matla and Kriel is a common occurrence, since the power stations are situated so close together.

The airborne DOAS can also provide high resolution images, which depict the variability within plumes. The merging of the plumes from Matla and Kriel is seen in Figure 10. The typical expansion of the plume downwind of a source (Majuba power station, in this case) is shown in Figure 11. 


\section{Conclusion}

Satellite retrievals highlight the South African Highveld as having one of the highest NO2 tropospheric column densities in the world. However, average surface $\mathrm{NO}_{2}$ levels are generally below the proposed South African ambient air quality standards in industrial regions. $\mathrm{NO}_{\mathrm{x}}$ levels are highest in urban areas, where vehicles (and domestic coal combustion in low-income areas) are a significant source of $\mathrm{NO}_{\mathrm{x}}$ emissions, and surface temperature exacerbate the accumulation of pollutants. The results of this study suggest that emissions of $\mathrm{NO}_{\mathrm{x}}$ in urban areas from vehicles and domestic burning pose a much greater risk to human health than emissions from tall stacks.

High resolution measurements of $\mathrm{NO}_{2}$ tropospheric column density collected with an airborne DOAS have shown that there is considerable variability in $\mathrm{NO}_{2}$ column densities over the Highveld, and $\mathrm{NO}_{2}$ plumes are clearly discernible tens of kilometres downwind of the sources.

\section{Acknowledgements}

The South African Weather Service in Bethlehem, particularly Nico Kroese, Xolile Ncipha and Steve Edwards, is thanked for their support during the flight campaigns. The South African Weather Service's research aircraft was used for the flights with the DOAS instrument. The Wits team, headed by Stephen Broccardo, is driving this project. The DOAS was loaned from the University of Heidelberg (Prof Uli Platt). Dr Klaus-Peter Heue is thanked for his invaluable contribution in installing and operating the DOAS, and analysing the data.

\section{References}

Annegarn, H.J., Kneen, M.A. and Lupankwa, M.: 2003, An investigation of $\mathrm{NO}_{\mathrm{x}}$ production from lightning over southern Africa using data from lightning imaging sensor (LIS) satellite and the ground based lightning positioning and tracking system (LPATS), Research Report RES/RR/03/20365, Eskom Holdings Ltd, Johannesburg.

Beirle, S., 2004: Estimating source strengths and lifetime of Nitrogen Oxides from satellite data, $\mathrm{PhD}$ thesis, University of Heidelberg, Germany

Broccardo, S.P., Heue, K.-P, Ross, K.E., Piketh, S.J. and Platt, U., 2007: Airborne Imaging DOAS: Results from the South African Highveld, International Conference on Atmospheric Sciences and Applications to Air Quality (ASAAQ), Hong Kong, 14-16 May 2007.
Ferguson, K. and Ross, K., 2006: NOx or not: A baseline assessment of ground-level nitrogen oxide levels over the South African Highveld, Eskom Research Report RES/RR/ 06/2855 1, Eskom, Cleveland.

Heue, K.-R, Wagner, T., Broccardo, S. P., Piketh, S.J., Ross, K.E. and Platt, U., 2007: Direct observation of twodimensional trace gas distributions with an airborne imaging DOAS instrument, European Geosciences Union (EGU) General Assembly, Vienna, 15-10 April 2007.

Lal, S. and Patil, R.S., 2001: Monitoring of atmospheric behaviour of NOx from vehicular traffic, Environmental Monitoring and Assessment, 68, 37 - 50.

Lee, D.S., Kohler, 1., Grobler, E., Rohrer, F., Sausen, R., Gallardo-Klenner, L., Olivier, J.G.J., Dentener F.J. and Bouwman, A.F., 1997: Estimations of global NOx emissions and their uncertainties, Atmospheric Environment., 31, 1735 -1749 .

Leue, C, Wenig, M., Wagner, T., Klimm, O., Platt, U. and Jahne, B., 2001: Quantitative analysis of NOx from Global Ozone Monitoring Experiment satellite image sequences, Journal of Geophysical Research, 106 (D6), 5493 - 5505.

Parsons, D.A. and Scholes, M.C., 1996: Biogenic NO emissions from savanna soils as a function of fire regime, soil type, soil nitrogen, and water status, Journal of Geophysical Research, 101 (D19), 23683 - 23688.

Seinfeld, J.H. and Pandis, S.N., 1998: Atmospheric Chemistry and Physics: From Air Pollution to Climate Change, Wiley, New York, 67 - 96, 234 - 263.

Sillman, S., 2000: Ozone production efficiency and loss of NOx in power plant plumes: Photochemical model and interpretation of measurements in Tennessee, Journal of Geophysical Research, 105 (D7), 9189-9202.

Wenig, M., Spichtinger, N., Stohl, A., Held, G., Beirle, S., Wagner, T., Jahne, B., and Platt, U., 2003: Intercontinental transport of nitrogen oxide pollution plumes, Atmospheric Chemistry and Physics, 3, 387 - 393. 


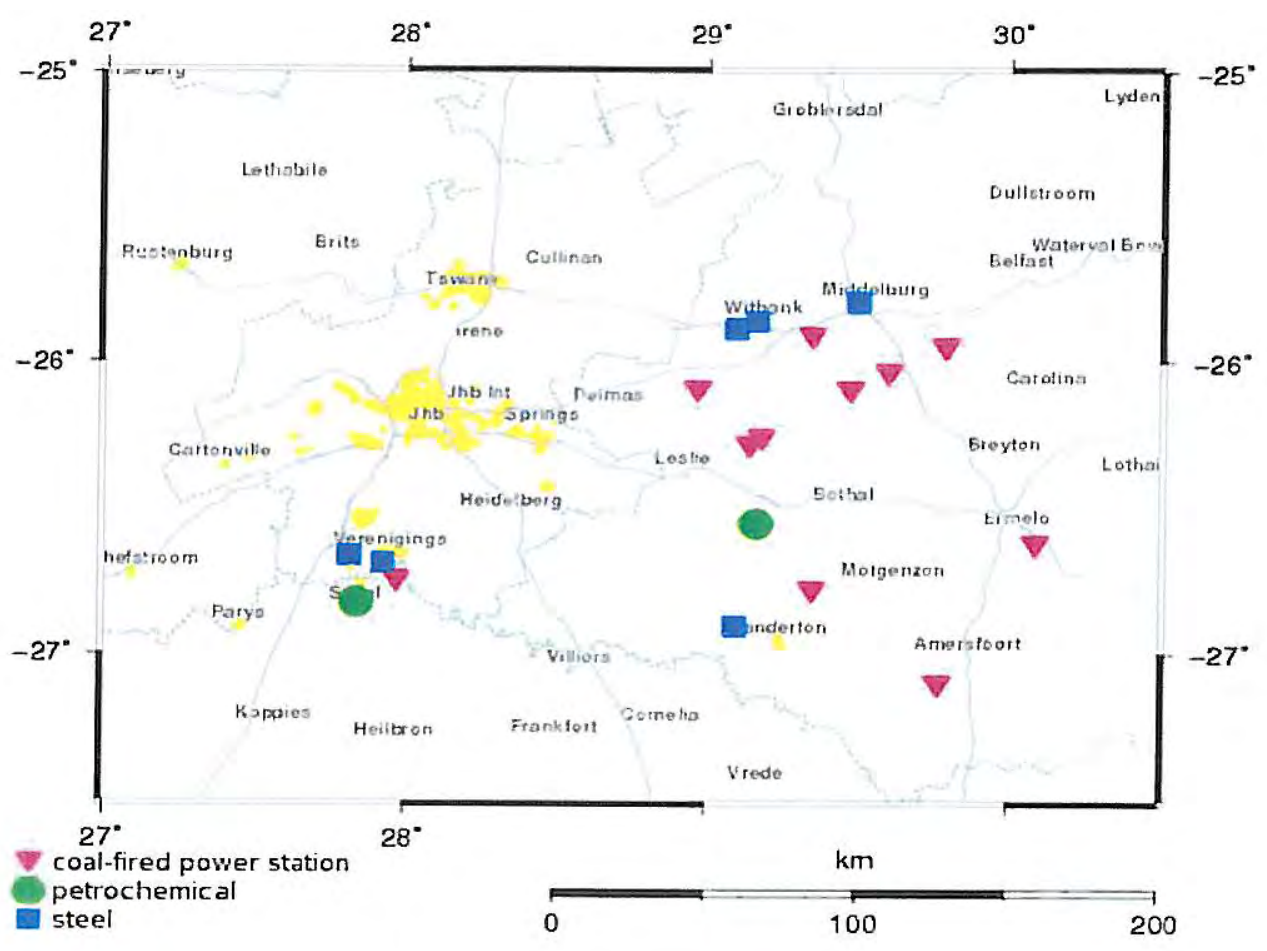

Figure 1: Location of urban areas, power plants and major industries on the South African Highveld (Broccardo et al., 2007)

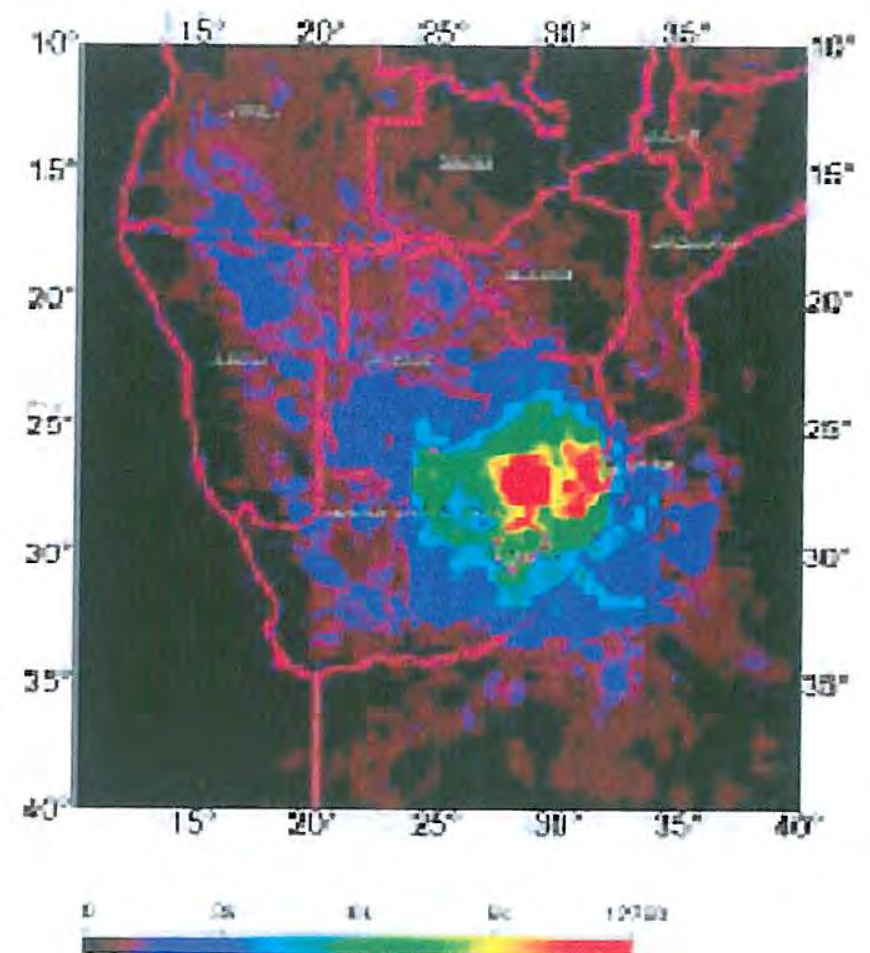

Figure 2: Lightning strike frequency plot (for January 2002) taken from the Lightning Positioning And Tracking System (LPATS) (Annegarn et al., 2003, 4) 


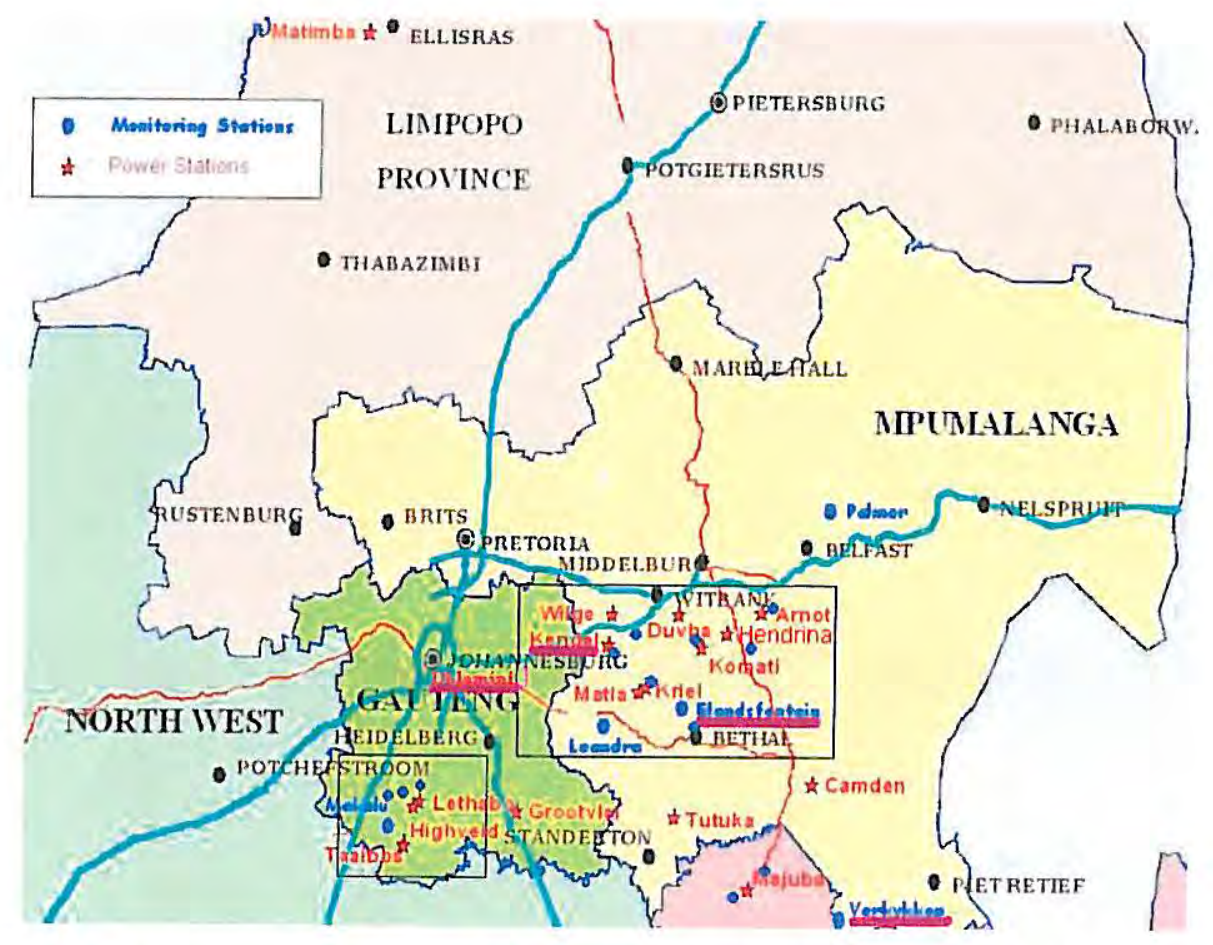

Figure 3: Eskom's power stations and air quality monitoring sites on the South African Highveld. Monitoring sites considered in this study are underlined in pink (Eskom intranet, 2006)
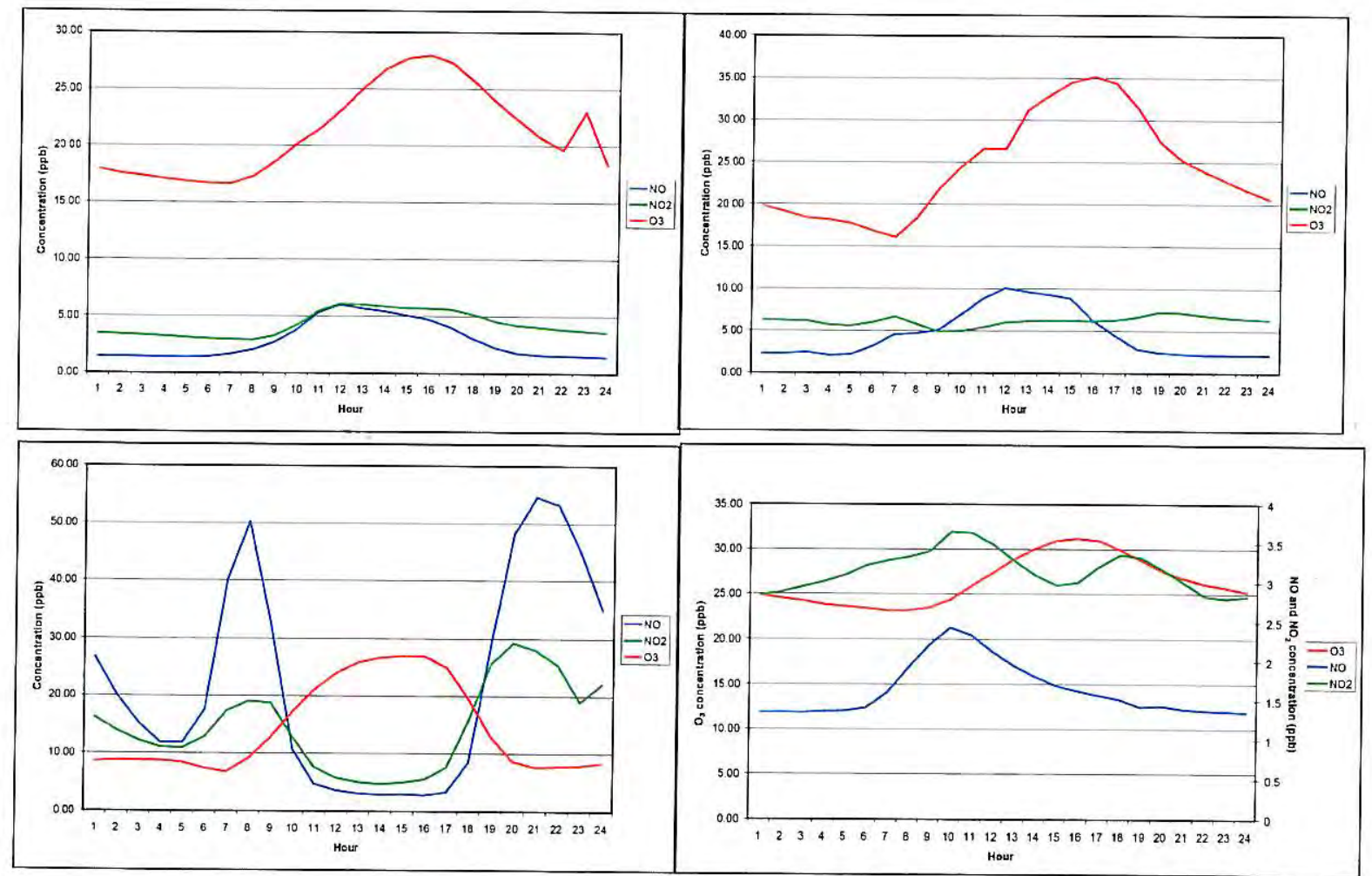

Figure 4: Average hourly $\mathrm{NO}_{x}$ and $\mathrm{O}_{3}$ concentrations in the industrial region (Elandsfontein; 19902005; upper left); directly downwind of a power station (Kendal; 1994-2004; upper right); in a township (Dhlamini; 1991-1992; lower left) and downwind of the Highveld (Verkykkop; 1990-2004; lower right) (Ferguson and Ross, 2006) 


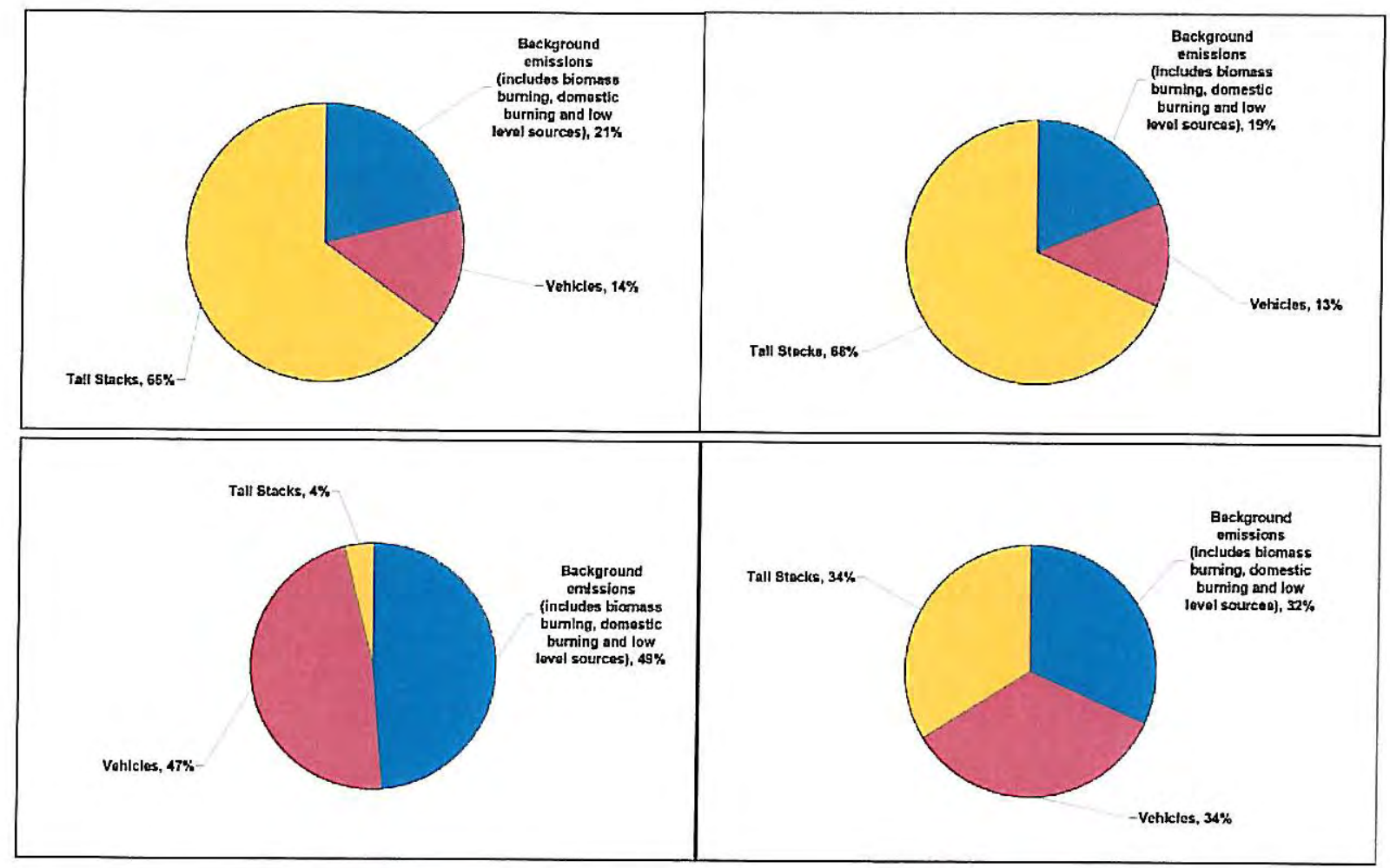

Figure 5: Relative contribution of sources to mean NO concentrations in the industrial region (Elandsfontein; upper left); directly downwind of a power station (Kendal; upper right); in a township (Dhlamini; lower left); and downwind of the Highveld (Verkykkop; lower right) (Ferguson and Ross, 2006)

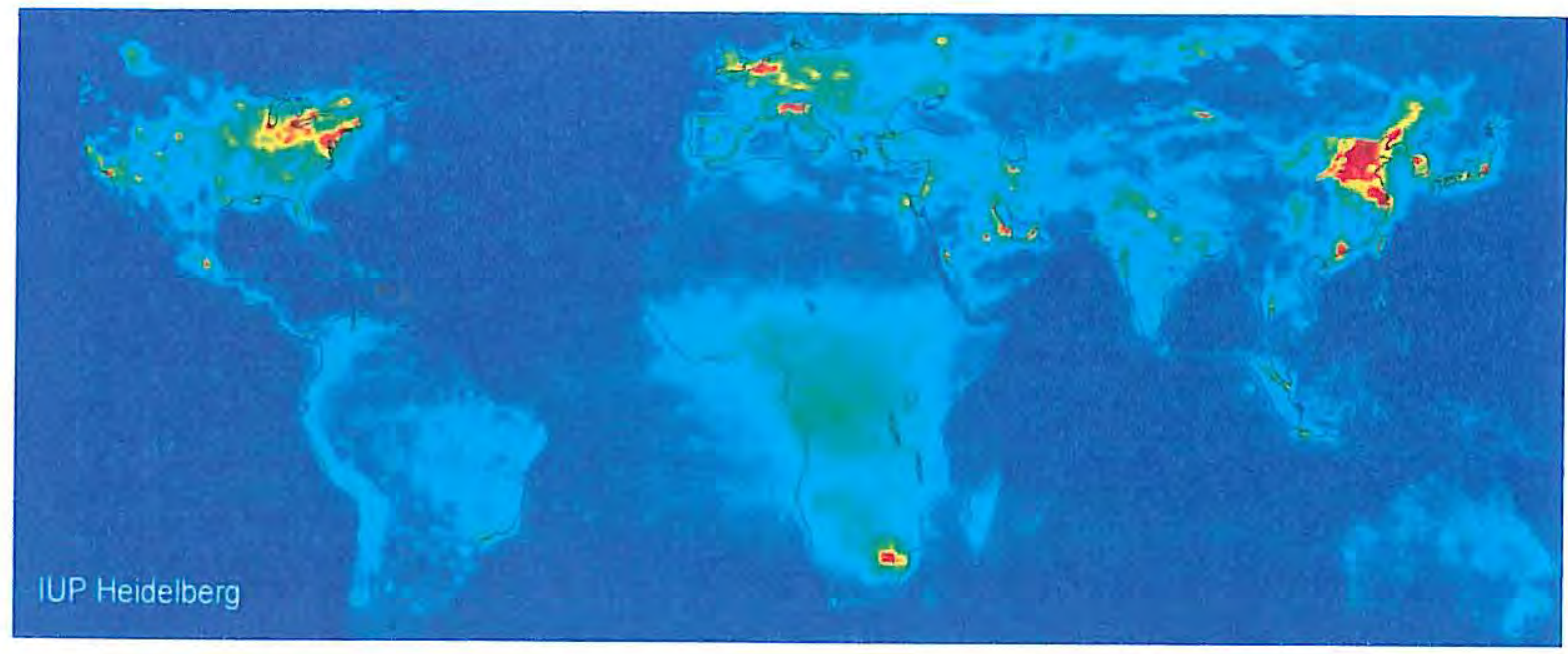

Figure 6: Mean tropospheric vertical column density from SCIAMACHY

(January 2003 - June 2004) (http://satellite.iup.uni-heidelberg.de/) 


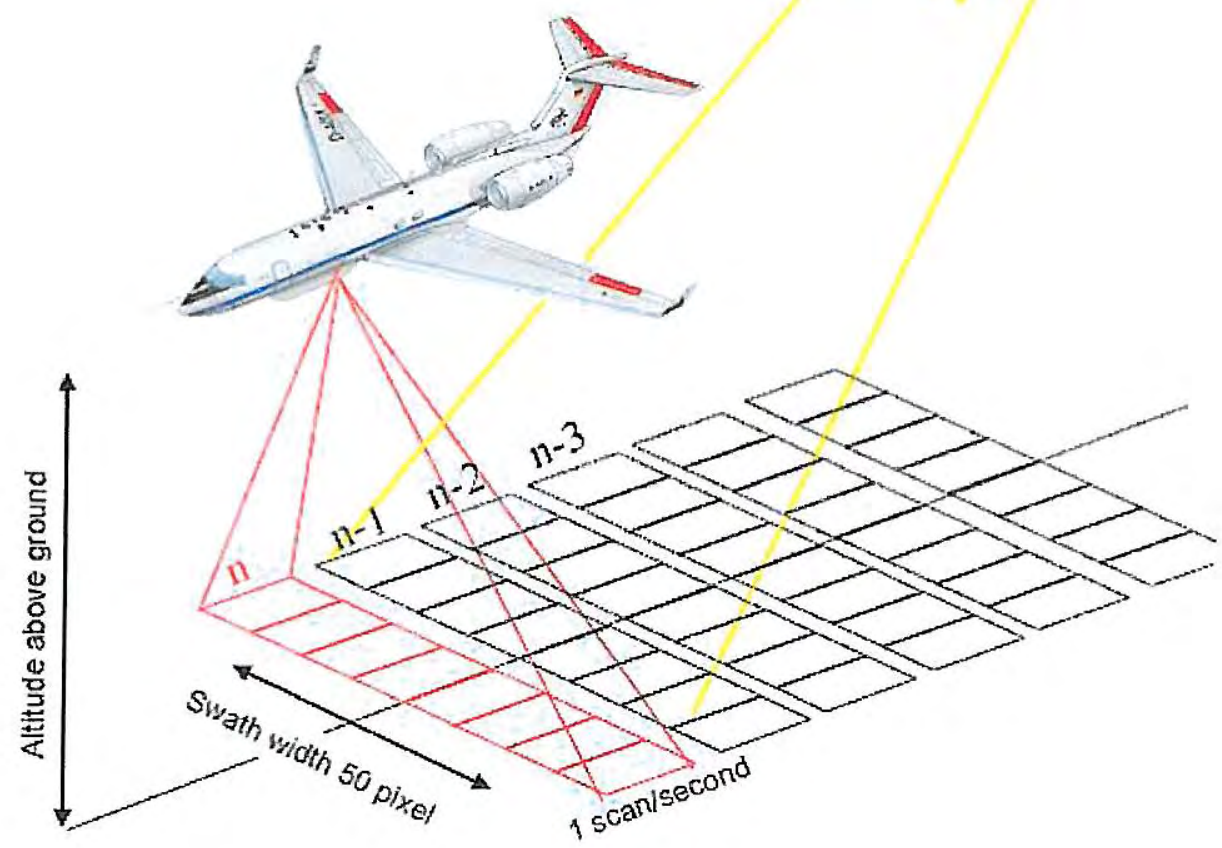

Figure 7: The airborne IDOAS technique (Heue et al., 2007)

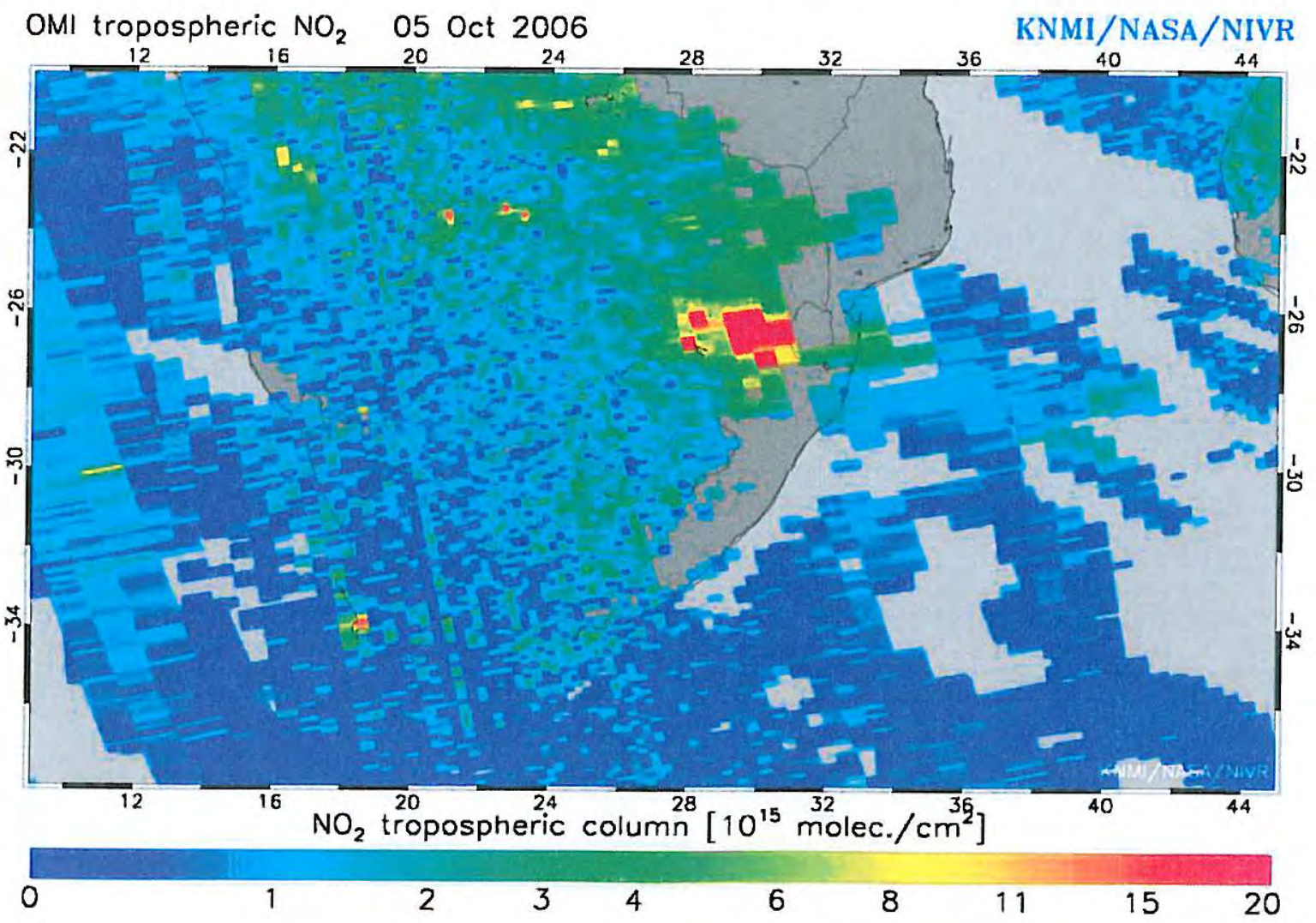

Figure 8: $\mathrm{NO}_{2}$ tropospheric column density on 5 October 2006, derived from OMI data 


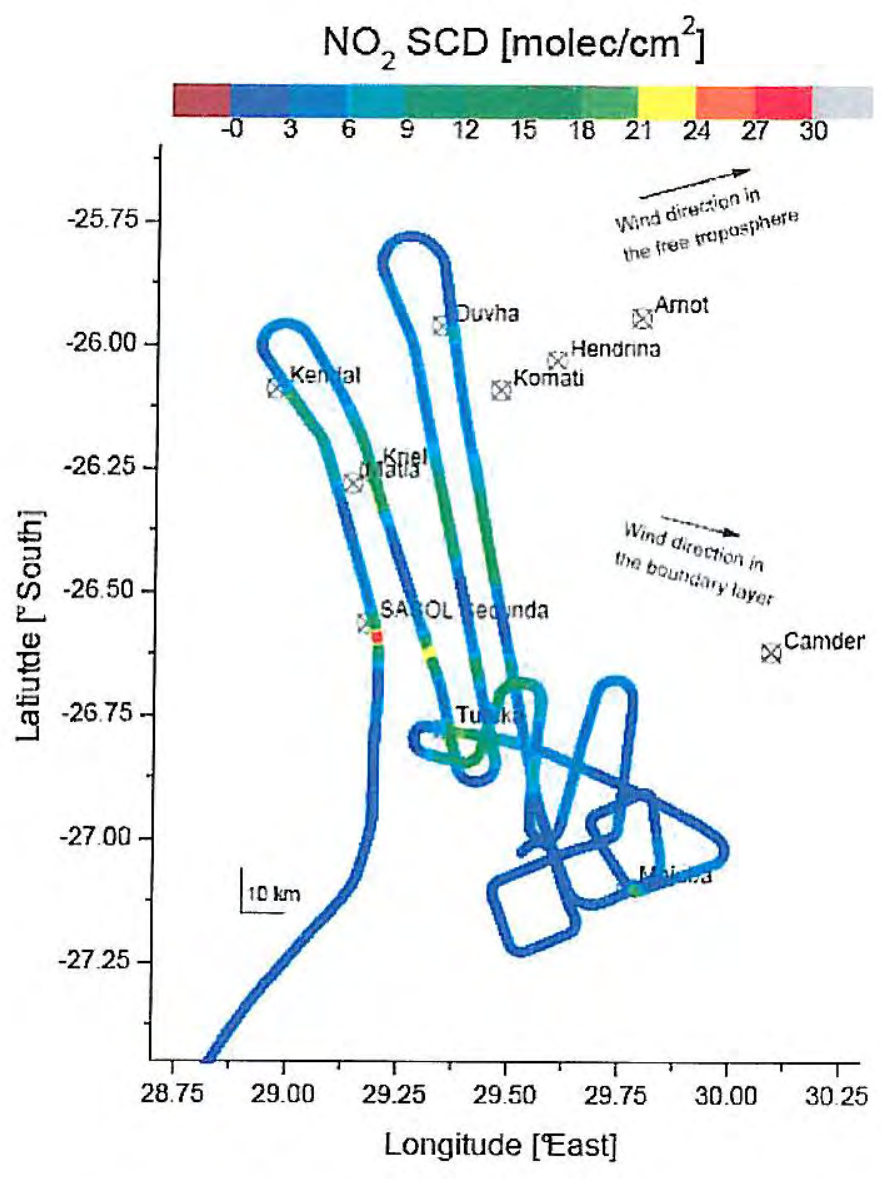

Figure 9: $\mathrm{NO}_{2} \mathrm{SCD}$ on the flight track on 5 October 2006 (Heue et al., 2007)

\section{Flight Direction}

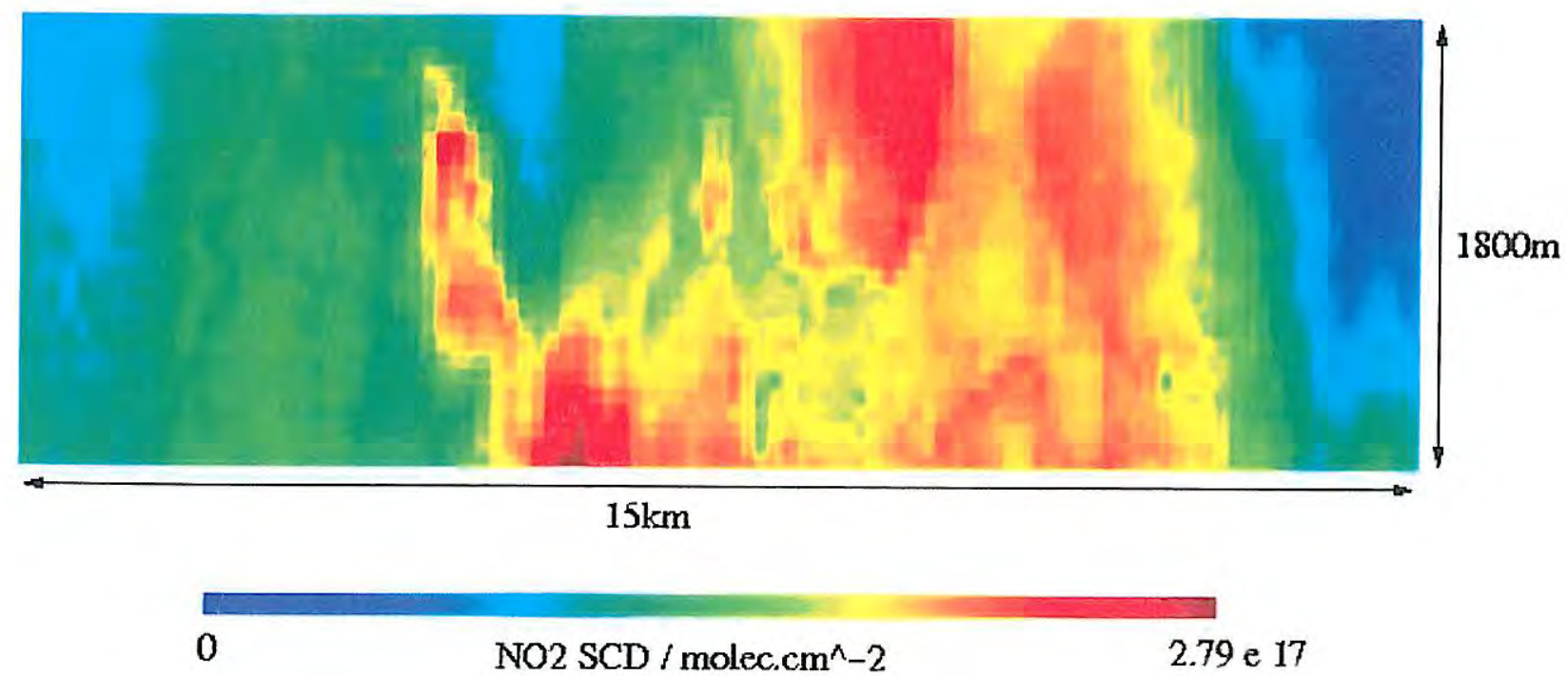

Figure 10: High resolution two-dimensional image of the plumes from Matla and Kriel, from the airborne iDOAS (Broccardo, 2007) 

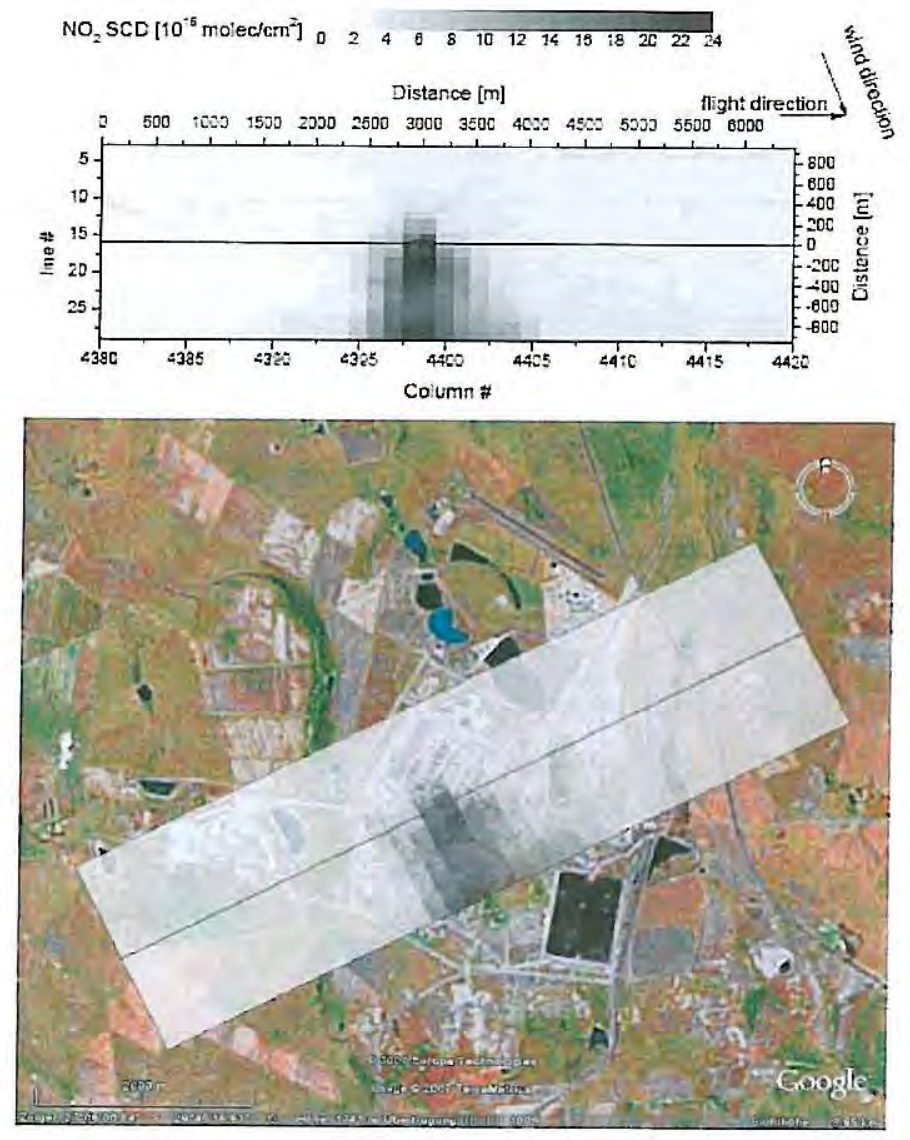

Figure 11: $\mathrm{NO}_{2} \mathrm{SCD}$ near Majuba power station (Heue et al., 2007) 